\title{
Genetic Variability, Heritability and Genetic Advance of Some Varieties of Tef (Eragrostis Tef (Zucc.) Trotter) in North West Ethiopia
}

\author{
Abebe Bogale* \\ Department of plant science, Mizan Tepi University, PO box 260Mizan-Teferi, Ethiopia \\ *Corresponding Author: Abebe Bogale, Department of plant science, Mizan Tepi University, PO box \\ 260Mizan-Teferi, Ethiopia
}

\begin{abstract}
Assessing variability is fundamental to identify the most important traits in tef improvement program. The objective of the present study was to estimate variability, heritability and genetic advance based on ten morphological characters of tef (Eragrostis tef (Zucc.) Trotter). The experiment was conducted in 2012 main cropping season at Adet Agricultural Research Center using randomized complete block design with three replications. Analysis of variance revealed significant difference $(p<0.01)$ among treatments for culm length, plant height, number of primary panicle branches, days to heading, days to maturity, days to grain fill period, grain yield, biomass yield and panicle length and $(p<0.05)$ harvesting index. The maximum variability between phenotypic and genotypic coefficient of variation was recorded for number of primary panicle branch $(15.5 \%, 10.3 \%)$ followed by panicle length $(12.03 \%, 8.0 \%)$. High phenotypic coefficient of variation $(P C V)$ was recorded for culm length (10.1\%), panicle length (12.0\%), and primary panicle branch $(15.5 \%)$, grain yield (16\%), biomass yield (11.0\%), and harvest index. Similarly, high genotypic coefficient of variation $(G C V)$ was observed for both grain yield (12.9\%) and primary panicle branch (10.3\%). Maximum heritability estimate were observed for days to maturity (93\%), days to heading (86\%), days to grain fill period (73.3\%), culm length (72\%), grain yield (65.2\%) and plant height (60.3\%). The rest quantitative trait exhibited moderate broad sense heritability values. The expected genetic advance as percentage of mean (GA\%) was relatively high for grain yield (21.4\%), day to heading (16.2\%), number of primary panicle branches (14.1\%), culm length (14.9\%) and days to grain fill period (12.7\%). High heritability with high genetic advance (as percentage of the mean) was observed for grain yield. High heritability coupled with moderate genetic advance as percent of mean was observed for day to heading, culm length, grain filling period, day to maturity and plant height which indicates that the characters can be improved through selection. Estimation of phenotypic correlation coefficient among traits indicated that there was positive and highly significant correlation between grain yield and culm length (0.84), plant height (0.82), days to heading (0.79), biomass yield (0.88), and harvest index (0.84). Grain yield had positive and highly significant genotypic correlation with plant height (0.71), culm length (0.62), days to heading (0.79), biomass yield (0.78), and harvest index (0.73) and also positively and significantly correlated with panicle length (0.51).Therefore, any improvement of these characters would result in a substantial increment on grain yield. Evaluation for variability of tef using conventional approach still could provide vital information but using contemporary molecular genetic analysis approaches such as mapping of quantitative trait loci using molecular markers is helpful to understand variability at molecular level, improve selection knowledge and arrive at more comprehensive conclusions. Repeating the experiment is advisable to better estimate environmental effects.
\end{abstract}

Keywords: Genetic advance, Heritability, Tef, Variability

\section{INTRODUCTION}

Tef (Eragrostis tef (zucc.)Trotter) is ancient and an important cereal crop in Ethiopia, where domestication took place before the birth of Christ (Seyfu, 1997).According to Stallknecht (1997), tef originated in Ethiopia around 4000-1000 BC. It was probably cultivated in Ethiopia even before the ancient introduction of emmer wheat and barley (Tadesse, 1975). The fact that several cultivated and wild species of Eragrostis, some of which were considered the wild relatives of tef, are found in Ethiopia and the genetic diversity existing in Ethiopia, indicated that tef originated and was domesticated in Ethiopia. Vavilov (1951) has identified Ethiopia as the center of origin and diversity of tef. 
Tef is adaptable to a wide range of ecological conditions in altitudes ranging from near sea level to $3000 \mathrm{msl}$ and even it can be grown in an environment unfavorable for most cereal, while the best performance occurs between 1100 and 2950 masl in Ethiopia (Hailu et al., 2000).

Tef is predominantly grown in Ethiopia as a food crop and not as a forage crop. However, when grown as a food, farmers highly value the straw of tef and it is stored and used as a very important source of animal feed, especially during the dry season. Farmers feed tef straw preferentially to lactating cows and working oxen. Cattle prefer tef straw to the straw of any other cereal and its price was higher than that of other cereals (Seyfu, 1997).

Tef is a hugely important crop to Ethiopia, both in terms of production and consumption. In a country of over 80 million people, tef accounts for about $15 \%$ of all calories consumed in Ethiopia. Furthermore, approximately 6 million households grow tef and it is the dominant cereal crop in over 30 of the 83 high-potential agricultural word as (Seyfu, 1997).

In Ethiopia, it is mainly produced in Amhara and Oromia, with smaller quantities in Tigray and South Nation Nationality People (SNNP) regions. In Amhara region, it is one of the major principal cereal crops and produced in East Gojjam, West Gojjam, North Gonder, South Gonder, North Wollo, South Wollo, North Shewa and Awi zones. However, the productivity of tef is very low (13.65 qt/ha). The causes of low yield levels is low yielding varieties, low yielding potential of the landraces, poor management practices, moisture stresses, susceptibility to lodging which is the major bottleneck for tef mechanization, and lower variation in landraces (Hailu et al., 2003). Therefore, assessing variability is fundamental to identify important traits for tef improvement. Knowledge of genetic variability, heritability and genetic advance provide more reliable information on variability, heritable trait, nature and level of interrelationship of tef yield and yield components. Therefore, the present study was conducted to understand the nature and extent of genetic variability, heritability and genetic advance in some important traits of tef genotypes.

\section{MATERials AND MethodS}

\subsection{Description of the Study Areas}

The experiment was carried in the field at Adet agriculture center during 2012/2013 main cropping season. The center is located at $37^{0} 29 \mathrm{E}$ and $11^{0} 16 \mathrm{~N}$ in the Amhara National Regional state. Adet is found $45 \mathrm{~km}$ from BahirDar along the main road that runs from BahirDar to Addis Ababa through Mota. It is located at $2240 \mathrm{masl}$ and receives an average annual of $18.2-25.3^{\circ} \mathrm{C}$ rain fall of $1230 \mathrm{~mm}$ with mean annual temperature. The dominant soil type of the area is nitosol

\subsection{Experimental Materials}

The material used in the study comprised of twelve genotype of tef. All of these materials are released varieties that obtained from Adet agricultural center.

Table1. List of tef (Eragrostis) genotypes used in this study

\begin{tabular}{|c|c|c|c|}
\hline № & Variety & Code & Year of Release \\
\hline 1 & Quncho & DZ-Cr-387(RIL355) & 2006 \\
\hline 2 & Etsub & DZ-01-3186 & 2008 \\
\hline 3 & Yilmana & DZ-1868 & 2005 \\
\hline 4 & Dima & DZ-2423 & 1984 \\
\hline 5 & Tsedey & DZ-Cr-37 & 2009 \\
\hline 6 & Simada & DZ-Cr-385 & 2005 \\
\hline 7 & Zoble & DZ-01-1821 & 2007 \\
\hline 8 & Gemechis & DZ-cr-387(RIL127) & 2005 \\
\hline 9 & Gembichu & DZ-01-899 & 1995 \\
\hline 10 & Dukem & DZ-01-2675 & 2005 \\
\hline 11 & Dega tef & & \\
\hline 12 & Local seed & & \\
\hline
\end{tabular}

\subsection{Experimental Design}

The experiment was laid out RCBD with three replications and the plot size of $2 \mathrm{mx} 2 \mathrm{~m}$. The spacing were $1 \mathrm{~m}$ between plots and $1.5 \mathrm{~m}$ between adjacent blocks. Each genotype was sown at seed rate of 25 
$\mathrm{kg} / \mathrm{ha}$ by method of planting was broadcasting. A recommended fertilizer rate $130 \mathrm{~kg} / \mathrm{ha}$ DAP during planting and $53 \mathrm{~kg} / \mathrm{ha}$ urea after twenty five days of sowing were applied. All other trial management activities were carried out as deemed necessary. Planting date was July 2012.

\section{Data Collection}

The following quantitative data were recorded from field observation 1):

a) Day from planting to heading

Number of days from planting to $50 \%$ heading of the plants in a plot.

b) Days to maturity

Number of days taken from date of sowing to physiological maturity of the plants

c) Days to grain fill period

Number of days from $50 \%$ heading of the plants to maturity

d) Culm length $(\mathrm{cm})$

The heights of the five plants selected at random were measured at harvesting time in centimeter. The height was taken as the distance between the soil surfaces to the beginning of panicle.

e) Panicle length (cm)

Heights of the five plants selected at random measured at harvesting time in centimeter; height was taken as the distance between the ends of Culm to tip of panicle

f) Plant height (cm)

Height of the main stem from the ground level to the tip of the main stem measured in centimeters at the time of harvesting

g) Number of primary branches per plant

Counting the total number of primary branches on main stem of each selected plant at the time of harvest

h) Grain yield per plot $(\mathrm{kg})$

Weight of the total grains on each plot of a particular variety obtained and recorded asgrain yield per plot

i) Biomass yield per plot $(\mathrm{kg})$

Total biological yield (biomass) produced at each plot recorded and expressed in kilogram

j) Harvest index (\%)

Ratio of seed yield to the total biological yield per plot expressed in percentage

Harvest index $(\mathrm{HI})=\frac{\text { Seed yield } / \text { plot }(\mathrm{kg})}{\text { Total biological yield } / \text { plot }(\mathrm{kg})} \times 100$

\subsection{Statistical Analysis}

\subsubsection{Analysis of variance (ANOVA)}

The data was subjected to analysis of variance using SAS software v 9.1.3 (SAS, 2004). The significant difference among genotypes was tested by ' $\mathrm{F}$ ' test at $1 \%$ and $5 \%$ levels of probability. The structure of analysis of variance (ANOVA) table is presented below.

Table2. The structure of analysis of variance (ANOVA) (Gomez and Gomez, 1998)

\begin{tabular}{|c|c|c|c|c|}
\hline Source & Df & (SS) & $(\mathrm{MS})$ & $\mathrm{F}$ \\
\hline Block & $\mathrm{r}-1$ & SSB & SSB/(r-1 & MSR/MSE \\
\hline Treatment & $\mathrm{t}-1$ & SST & SST/(t-1) & MST/MSE \\
\hline Error & (r-1)(t-1) & TSS-SST-SSB & SSE(r-1)(t-1) & \\
\hline Total & tr-1 & TSS & & \\
\hline
\end{tabular}


Where: $r=$ Number of replications; $t=$ Number of treatments / genotypes; $S S=$ Sum of square; $M S=$ Mean of square; $S . E m= \pm$ E.M.SS/r

Coefficient of variation $(\mathrm{CV} \%)=\frac{\sqrt{\text { ErrorMS }}}{\text { Grandmean }} X 100$

The significance was tested by referring the table given by Snecedor (1946).

\subsubsection{Components of variance}

The genotypic and phenotypic components of variance were computed according to formulae given by Burton and Devane (1953) for the observed characters.

$\mathrm{V}_{\mathrm{g}}=\frac{\mathrm{MST}-\mathrm{MSE}}{\mathrm{r}}$

Where: $\mathrm{V}_{\mathrm{g}}\left(\sigma^{2} \mathrm{~g}\right)=$ genetic variance; MST=mean square of treatment; MSE $(\mathrm{Ve})=$ Error variance $\mathrm{r}=$ Number of replications

Genotypic and Phenotypic variance

$\sigma^{2} \mathrm{~g}=\sigma^{2} \mathrm{p}-\sigma^{2} \mathrm{e}$

$\sigma^{2} \mathrm{p}=\sigma^{2} \mathrm{~g}+\sigma^{2} \mathrm{e}$

Where: $\sigma^{2} \mathrm{~g}=$ genetic variance; $\sigma^{2} \mathrm{p}=$ phenotypic variance; $\sigma^{2} \mathrm{e}=$ error variance

\subsubsection{Genotypic and phenotypic Coefficient of variability}

Genotypic and phenotypic coefficients of variability were computed according to Burton and Devane (1953).

Genotypic coefficient of variability $(\mathrm{GCV})=\frac{\sqrt{\sigma 2 g}}{x} \times 100$

Phenotypic coefficient of variability $(\mathrm{PCV})=\frac{\sqrt{\sigma 2 p}}{\mathrm{x}} \times 100$

Environmental coefficient of variability $(\mathrm{ECV})=\frac{\sqrt{\sigma 2 e}}{x} \mathrm{x} 100$

Where, $\sigma_{\mathrm{g}}^{2}=$ Genotypic variance

$\sigma_{\mathrm{p}}^{2}=$ Phenotypic variance and

$\sigma_{\mathrm{e}}^{2}=$ Environmental variance

$\mathrm{X}=$ General mean of character

The PCV and GCV values are ranked as low, medium and high (Shivasubramanian and Menon, 1973) as follows: 0-10\% - Low; 10-20\% - Moderate; >20\% - High

\subsubsection{Heritability}

Broad sense heritability was estimated based on the ratio of genotypic variance to the phenotypic variance and was expressed in percentage (Falconer and Mackay, 1996).

$\mathrm{h}_{\mathrm{B}}^{2}=\frac{\mathrm{V}_{\mathrm{g}}}{\mathrm{V}_{\mathrm{p}}} \times 100$

Where: $h^{2}{ }_{B}=$ heritability in broad sense; $V_{g}=$ Genotypic variance; $V_{p}=$ Phenotypic variance

Heritability values are categorized as low, moderate and high (Robinson et al., 1949) as follows: 030\%: Low; 30-60\%: Moderate; 60\% and above: High

\subsubsection{Genetic Advance}

The extent of genetic advance is expected by selecting certain proportion of the superior progeny was calculated by using the following formula given by Robinson et al., (1949).

Genetic advance $(\mathrm{GA})=\mathrm{k} \sigma_{\mathrm{p}} \mathrm{h}^{2}$ 
Where: $\mathrm{k}=$ Intensity of selection at $5 \%(\mathrm{k}-2.06) ; \sigma_{\mathrm{p}}=$ Phenotypic standard deviation; $\mathrm{h}^{2}=$ Heritability in broad sense

The value of ' $\mathrm{k}$ ' was taken as 2.06 assuming $5 \%$ are selected.

3.1.6. Genetic Advance Expressed as Percentage over Mean (GAM)

$\mathrm{GAM}=\frac{\mathrm{GA}}{\overline{\mathrm{X}}} \times 100$

Where: $\mathrm{GA}=$ Genetic advance; $\mathrm{x}=$ General mean of the character

The GAM was categorized as suggested by Johnson et al. (1955) as: 0-10\% = Low; $11-20 \%=$ Moderate; $>20 \%$ and above High

\subsubsection{Estimation of Correlation Coefficient}

In all the generation, the simple correlation coefficients were calculated to determine the degree of association of different characters with seed yield and its components in each of the population separately. Correlation coefficients were compared against r-table values (Fisher and Yates, 1963) at $(\mathrm{n}-2) \mathrm{df}$ at the probability levels at 0.05 and 0.01 to test their significance. Genotypic (Vg) and phenotypic $(\mathrm{Vp})$ Correlation coefficient between two variables was estimated using the following formula suggested by Falconer and Mackay (1996).

Genotypic correlation $=r_{X Y}(g)=\frac{\operatorname{coV}_{X Y}(g)}{\sqrt{V_{X}(p) \times V_{Y}(g)}}$

Phenotypic correlation $=r_{X Y}(p)=\frac{\operatorname{coV}_{X Y}(g)}{\sqrt{V_{X}(p) \times V_{Y}(p)}}$

Where:

$\operatorname{COV}_{\mathrm{xy}}(\mathrm{g})=$ Genotypic covariance between $\mathrm{x}$ and $\mathrm{y}$

$\operatorname{COV}_{\mathrm{xy}}(\mathrm{p})=$ Phenotypic covariance between $\mathrm{x}$ and $\mathrm{y}$

$\mathrm{V}_{\mathrm{x}}(\mathrm{g})=$ Genotypic variance of characters $\mathrm{x}$

$\mathrm{V}_{\mathrm{y}}(\mathrm{g})=$ Genotypic variance of character $\mathrm{y}$

$\mathrm{V}_{\mathrm{y}}(\mathrm{p})=$ Phenotypic variance of character $\mathrm{y}$

$\mathrm{V}_{\mathrm{x}}(\mathrm{p})=$ Phenotypic variance of characters $\mathrm{x}$

Test of significance of correlations was tested by comparing the computed values against table ' $r$ ' values, given by Fisher and Yates (1963).

\section{RESULTS AND DISCUSSION}

The present experiment was carried out to assess the nature and extent of genetic variability, heritability and genetic advance of 12 germplasm accessions of tef. The data obtained were subjected to statistical analysis to find out means, genetic parameters and correlations among the different characters.

The results obtained in the present investigation are discussed here under.

\subsection{Analysis of Variance}

The analysis of variance revealed that there was highly significant differences among genotypes for Culm length, plant height, number of primary panicle branches, day to heading, day to maturity, days to grain fill period, grain yield and biological yield per plot. Panicle length and harvesting index were significant at 5\%. The results generally showed the existence of genotypic variability in the cultivars studied. The best genotypes could be extended or used for further breeding program. These results were further supported by Wondewosen et al2012 who reported considerable variation in the grain yield and yield related traits.

Table3. Analysis of variance for different characters of tef germplasm

\begin{tabular}{|c|c|c|c|c|c|c|c|c|c|c|c|}
\hline $\begin{array}{c}\text { Sources } \\
\text { of }\end{array}$ & & CL & PL & PH & DH & DM & GFP & PPB & GY & BMY & HI \\
\cline { 1 - 9 } variation & $d f$ & & & & & & & & & \\
\hline MSR & 2 & $\begin{array}{c}58.6 \\
2\end{array}$ & 7.79 & 116.8 & 6.86 & 9.08 & 0.19 & $\begin{array}{c}108.2 \\
7\end{array}$ & 0.039 & 0.119 & 17.09 \\
\hline
\end{tabular}


Genetic Variability, Heritability and Genetic Advance of Some Varieties of Tef (Eragrostis Tef (Zucc.) Trotter) in North West Ethiopia

\begin{tabular}{|c|c|c|c|c|c|c|c|c|c|c|c|}
\hline MST & 11 & $\begin{array}{c}123 . \\
2 * *\end{array}$ & $\begin{array}{c}37.6 \\
* *\end{array}$ & $235.13 * *$ & $\begin{array}{c}95.06^{*} \\
*\end{array}$ & $116^{* *}$ & $\begin{array}{c}53.17 * \\
*\end{array}$ & $\begin{array}{c}15.5^{*} \\
*\end{array}$ & $\begin{array}{c}0.09 * * \\
0.39 * \\
*\end{array}$ & $\begin{array}{c}15.77 \\
*\end{array}$ \\
\hline MSE & 35 & $\begin{array}{c}14.0 \\
7\end{array}$ & $\begin{array}{c}11.1 \\
4\end{array}$ & 42.29 & 4.89 & 2.69 & 5.74 & 4.58 & 0.0141 & $\begin{array}{c}0.109 \\
4\end{array}$ & 6.75 \\
\hline CV $(\%)$ & & 5.32 & 8.99 & 6.05 & 3.4 & 1.37 & 4.35 & 11.5 & 9.4 & 8.03 & 8.53 \\
\hline SE & & $\begin{array}{c} \pm 2.1 \\
6\end{array}$ & \pm 1.9 & \pm 3.75 & \pm 1.27 & \pm 0.95 & \pm 1.38 & \pm 1.23 & \pm 0.068 & \pm 0.19 & \pm 1.5 \\
\hline
\end{tabular}

$*$ = Significant at $5 \%$ level of probability, $* *=$ highly Significant at $1 \%$ level of probability, $n s=$ Not significant, $C L=C$ ulm length, $P L=$ panicle length, $P H=$ plant height, DH=days to heading, DM days to maturity, $G F P=$ grain filling period, $P P B=$ primary panicle brunch, $G Y=$ grain yield, BMY=biomass yield, HI=harvest index, MSR=mean square of replication, MST= mean square of treatment, MSE =mean square of error, $C V=$ coefficient of variation and $S E=$ standard error.

\subsection{Range and Mean of Different Characteristics}

Estimated range, mean and standard error of the mean for the ten characters are presented in Tables 4. There is a wide range of variability obtained from the characters

Table4. Mean and Range values for different agronomic traits for 12 cultivars at Adet in 2012

\begin{tabular}{|c|c|c|c|c|c|c|c|c|c|c|}
\hline & $\mathrm{CL}$ & PL & $\mathrm{PH}$ & PPB & $\mathrm{DH}$ & DM & GFP & GY & BM & $\mathrm{HI}$ \\
\hline Mean & 70.50 & 37.13 & 107.4 & 18.54 & 64.53 & 119.5 & 55.11 & 3138.7 & 10344.9 & 37.13 \\
\hline Adet local & $64.53^{\text {def }}$ & $35.5^{\mathrm{cd}}$ & $100.1^{\mathrm{cd}}$ & $18.6^{\mathrm{b}}$ & $66^{\mathrm{bc}}$ & $121^{\mathrm{b}}$ & $55 \mathrm{~b}$ & $2790.8^{\mathrm{d}}$ & $9683.3^{\text {bcd }}$ & $28.9^{\text {bcd }}$ \\
\hline $\begin{array}{c}\text { DZ-CR- } \\
385\end{array}$ & $59.6^{\mathrm{f}}$ & $37.6^{\text {abc }}$ & $96.6^{\mathrm{d}}$ & $14.4^{\mathrm{c}}$ & $52^{\mathrm{e}}$ & $105^{\mathrm{e}}$ & $53 \mathrm{bc}$ & $2245.5^{\mathrm{e}}$ & $8401.7^{\mathrm{d}}$ & $26.6^{\mathrm{d}}$ \\
\hline DZ-2423 & $67.53^{\text {cde }}$ & $33.6^{\mathrm{cd}}$ & $99.9^{\text {cd }}$ & $19.6^{\mathrm{ab}}$ & $63.3^{\mathrm{c}}$ & $117.6^{\mathrm{c}}$ & $54.3 b$ & $3097.3^{\text {bcd }}$ & $10525.8^{\mathrm{abc}}$ & $29.8^{\text {abc }}$ \\
\hline DZ-1868 & $72.66^{\mathrm{bc}}$ & $35.8^{\text {bcd }}$ & $108.5^{\text {bcd }}$ & $16.5^{\mathrm{bc}}$ & $66.6^{\mathrm{bc}}$ & $120 \mathrm{~b}^{\mathrm{c}}$ & $53.3 \mathrm{bc}$ & $3006.7^{\mathrm{cd}}$ & $9442.5^{\mathrm{cd}}$ & $31.8^{\mathrm{abc}}$ \\
\hline DZ-C -37 & $63^{\mathrm{ef}}$ & $34.8^{\text {cd }}$ & $97.4^{d}$ & $17.8^{\mathrm{bc}}$ & $58.6^{\mathrm{d}}$ & $111.3^{\mathrm{d}}$ & $53.3 b c$ & $2982.6^{\mathrm{cd}}$ & $9401.7^{\mathrm{cd}}$ & $31.7^{\mathrm{abc}}$ \\
\hline $\begin{array}{c}\text { DZ-01- } \\
899 \\
\end{array}$ & $69.8^{\text {cde }}$ & $34.8^{\mathrm{d}}$ & $100.6^{\mathrm{cd}}$ & $16.4^{\mathrm{bc}}$ & $66^{\mathrm{bc}}$ & $121.3^{b}$ & $55.3 b$ & $2974.8^{\mathrm{cd}}$ & $10888.3^{\mathrm{abc}}$ & $28.5^{\text {bcd }}$ \\
\hline $\begin{array}{c}\text { DZ-01- } \\
2675\end{array}$ & $69.8^{\text {cde }}$ & $36.9^{\text {bcd }}$ & $106.7^{\text {bcd }}$ & $23.3^{\mathrm{a}}$ & $59^{d}$ & $126.3^{\mathrm{a}}$ & $67.3 a$ & $2793.4^{\mathrm{d}}$ & $10333.3^{\mathrm{abc}}$ & $27.3^{\mathrm{cb}}$ \\
\hline $\begin{array}{c}\text { DZ-Cr- } \\
387 \\
\text { (RIL-355) }\end{array}$ & $82.73^{\mathrm{a}}$ & $42.1^{\mathrm{ab}}$ & $124.8^{\mathrm{a}}$ & $18.9^{b}$ & $71.3^{\mathrm{a}}$ & $121^{b}$ & $49.6 \mathrm{c}$ & $3872.8^{\mathrm{a}}$ & $11361.7^{\mathrm{a}}$ & $34.1^{\mathrm{a}}$ \\
\hline $\begin{array}{c}\text { DZ-01- } \\
387 \\
\text { (RIL-127) }\end{array}$ & $71.13^{\mathrm{dc}}$ & $39.7^{\text {abc }}$ & $110.8^{\mathrm{bc}}$ & $20.6^{\mathrm{ab}}$ & $64^{\mathrm{c}}$ & $117.6^{\mathrm{c}}$ & $53.6 b c$ & $3591.9^{\mathrm{ab}}$ & $11294.2^{\mathrm{ab}}$ & $31.7^{\mathrm{abc}}$ \\
\hline $\begin{array}{c}\text { DZ-01- } \\
1821 \\
\end{array}$ & $78.20^{\mathrm{ab}}$ & $36.7^{\mathrm{bcd}}$ & $114.9^{\mathrm{ab}}$ & $17.4^{\mathrm{bc}}$ & $67.3^{\mathrm{abc}}$ & $120.7^{\mathrm{bc}}$ & $54.3 \mathrm{~b}$ & $3434.6^{\mathrm{abc}}$ & $10555^{\mathrm{abc}}$ & $33.1^{\mathrm{ab}}$ \\
\hline $\begin{array}{l}\text { DZ-01- } \\
974\end{array}$ & $74.13^{\mathrm{bc}}$ & $43.8^{\mathrm{a}}$ & $117.8^{\mathrm{ab}}$ & $20.1^{\mathrm{ab}}$ & $71^{\mathrm{a}}$ & $126.7^{\mathrm{a}}$ & $55.6 \mathrm{~b}$ & $3361.8^{\mathrm{abc}}$ & $10909.2^{\text {abc }}$ & $\begin{array}{c}30.7^{\text {abc }} \\
\text { d }\end{array}$ \\
\hline $\begin{array}{c}\text { DZ-01- } \\
3186\end{array}$ & $72.87^{\mathrm{bc}}$ & $38^{\mathrm{abc}}$ & $110.8^{\mathrm{bc}}$ & $18.6^{\mathrm{bc}}$ & $69^{\mathrm{ab}}$ & $125.3^{\mathrm{a}}$ & $56.3 b$ & $3512.8^{\mathrm{abc}}$ & $11342.5^{\mathrm{a}}$ & $31^{\text {abcd }}$ \\
\hline Alpha & $0.05^{*}$ & $0.05^{*}$ & $0.05^{*}$ & $0.05^{*}$ & $0.05^{*}$ & $0.05^{*}$ & $0.05^{*}$ & $0.05^{*}$ & $0.05^{*}$ & $0.05^{*}$ \\
\hline
\end{tabular}

$C L=$ Culm length, $P L=$ panicle length, PH=plant height, DH=days to heading, DM =days to maturity, $G F P=$ grain filling period, $P P B=$ primary panicle brunch, $G Y=$ grain yield, $B M Y=$ biomass yield, $H I=h a r v e s t$ index. Mean within a column followed by the same letter(s) within a column are not significantly different from each other at $5 \%$. by DMRT

\subsection{Phenotypic and Genotypic Coefficient of Variation}

The effectiveness of selection in any crop depends on the extent and nature of phenotypic and genotypic variability present in different agronomic traits of population (Arora, 1991). Generally, genetic parameters including genotypic coefficient of variation, heritability and genetic advance are prerequisite for genetic improvement of crops (Khorgade et al., 1985). High genotypic coefficient of variation indicates availability of high genetic variation. The lower value of variation indicates that selection is not effective for particular character because of the narrow genetic variability (Pandey and Tiwari, 1983; Arora, 1991).

According to Burton and Devane (1953) PCV and GCV values greater than 20\% are regarded as high, whereas values less than $10 \%$ are considered to be low and values between $10 \%$ and $20 \%$ to be medium. The phenotypic (PCV) and genotypic (GCV) coefficient of variations of the various tef characters computed are presented in table 5. In this study, PCV ranged from $5.1 \%$ for days to maturity to $16 \%$ for grain yield and the GCV ranged from $5.1 \%$ for days to maturity to $12.9 \%$ for 
grain yield. The maximum value between PCV and GCV was recorded for number of primary panicle branch $(15.5 \%-10.3 \%)$ followed by panicle length $(12.0 \%-8.0 \%)$. Generally, the GCV and PCV were similar in magnitude and direction which indicated that the genotypes were able to express their genetic potential for various traits. GCV of high order were not observed, but both grain yield (12.9\%) and primary panicle brunch $(10.3 \%)$ had moderate GCV. Other traits such as culm length $(8.6 \%)$, panicle length $(8.0 \%)$, plant height $(7.5 \%)$, days to heading $(8.5 \%)$, days to maturity $(5.14 \%)$, grain filling period (7.2\%), biomass yield $(7.6 \%)$ and harvest index $(6.6 \%)$ had low GCV. Earlier workers also reported relatively higher GCV for grain yield (kebebew et al., 2000; Habtamu, 2012). Similar results of lower GCV in days to heading $(8.5 \%)$, days to maturity $(5.1 \%)$ and grain filling period (7.2\%) were also reported by Habtamu Ayalew (2012).

Relatively higher PCV was observed for culm length (10.1\%), panicle length (12.0\%), primary panicle branch (15.5\%), grain yield (16\%), biomass yield (11.0\%) and harvest index (10.3\%). These findings are in conformity with earlier reports of Ayalneh T. et al.(2012) and Habtamu (2012). Similarly, Solomon et al. (2009) reported that grain yield; biomass yield and harvest index had highest PCV. Lower PCV was observed for plant height (9.7\%), day to heading $(9.2 \%)$, day to maturity (5.1\%) and days to grain fill period (8.4\%). Similarly, Ayalneh et al., 2012; Habtamu Ayalew, 2012 also reported lower PCV for days to heading and days to maturity.

Among all traits, moderate GCV and PCV values (>10\%) were observed for primary panicle branch and grain yield. therefore further selection of these traits could improve the genotype. Days to maturity showed low PCV and GCV $(<5 \%)$ suggesting the difficulty of manipulating such trait through plant breeding. Generally, the PCV values were greater than GCV values although the differences were not large suggesting that there was influence of the environment. The environmental coefficients of variation (ECV) of traits were lower than both genotypic and phenotypic coefficient of variations. This implies that the environmental role was less for the expression of such characters.

Table5. Genotypic, phenotypic and environmental coefficient of variation, genotypic, phenotypic and environmental variance, heritability and genetic advance (GA as \% of mean) of quantitative traits of 12 genotypes of tef

\begin{tabular}{|c|c|c|c|c|c|c|c|c|c|c|}
\hline$№$ & Traits & $\mathrm{V}_{\mathrm{p}}$ & $\mathrm{V}_{\mathrm{g}}$ & $\mathrm{V}_{\mathrm{e}}$ & PCV & $\mathrm{GCV}$ & $\mathrm{ECV}$ & $\mathrm{h}^{2}{ }_{\mathrm{B}} \%$ & $\mathrm{GA}$ & $\mathrm{GAM}$ \\
\hline 1. & CL & 50.44 & 36.37 & 14.07 & 10.1 & 8.6 & 5.3 & 72 & 10.5 & 14.9 \\
\hline 2. & PL & 19.96 & 8.82 & 11.14 & 12.03 & 8.0 & 8.9 & 44.2 & 4.07 & 10.96 \\
\hline 3. & PH & 106.57 & 64.28 & 42.29 & 9.65 & 7.5 & 6.05 & 60.3 & 12.8 & 11.94 \\
\hline 4. & PPB & 8.23 & 3.65 & 4.58 & 15.5 & 10.3 & 11.54 & 44.3 & 2.62 & 14.12 \\
\hline 5. & DH & 34.94 & 30.05 & 4.89 & 9.15 & 8.5 & 3.4 & 86 & 10.5 & 16.23 \\
\hline 6. & DM & 40.46 & 37.77 & 2.69 & 5.13 & 5.14 & 1.37 & 93 & 12.18 & 10.2 \\
\hline 7. & GFP & 21.55 & 15.81 & 5.74 & 8.42 & 7.2 & 4.3 & 73.3 & 7.01 & 12.72 \\
\hline 8. & GY & 252244.4 & 164333.4 & 87910.9 & 16 & 12.9 & 9.46 & 65.15 & 0.269 & 21.4 \\
\hline 9. & BMY & 1347877.4 & 626792.8 & 721084.6 & 11.04 & 7.6 & 8.04 & 46.9 & 0.438 & 10.64 \\
\hline 10 & HI & 9.757 & 4.01 & 6.7553 & 10.25 & 6.57 & 8.5 & 41.1 & 2.64 & 8.66 \\
\hline
\end{tabular}

of quantitative traits of 12 genotypes of tef

$C L=C$ ulm length, $P L=$ panicle length, $P H=$ plant height, DH=days to heading, DM =days to maturity, $G F P=$ grain filling period, $P P B=$ primary panicle brunch, $G Y=$ grain yield, $B M Y=$ biomass yield, $H I=h a r v e s t$ index, $G V=$ Genotypic variance, $G C V=$ Genotypic coefficient of variation, $h^{2}{ }_{B}=$ Heritability in broad sense, $P V=$ Phenotypic variance, $P C V=$ Phenotypic coefficient of variation GAM=Genetic advance as per cent of mean, GA-genetic advance

\subsection{Heritability and Expected Genetic Advance}

Information on heritability and genetic advance of yield attributing traits and their association with seed helps plant breeder to identify characters for effective selection (Misra, 1991). Heritability is an important factor to determine the response of selection and breeding program. Its estimations are important aspect of inheritance of quantitative traits as they indicate the genetic gains that may be gained through selection (Pandey and Tiwari, 1983). According to (Robinson et al., 1949) heritability values are categorized as low from $0-30 \%$, moderate from $30-60 \%$ and $60 \%$ and above are high. Considering this benchmark, heritability estimate was as follow.

Heritability $\left(\mathrm{h}_{\mathrm{B}}^{2}\right.$ ) estimate ranged from $41.1 \%$ for harvesting index to $93 \%$ for days to maturity (Table 5 ). Day to maturity (93\%), day to heading (86\%), days to grain fill period $(73.3 \%)$, culm length 
(72\%), grain yield $(65.2 \%)$ and plant height $(60.3 \%)$ exhibited relatively higher $\mathrm{h}^{2}{ }_{\mathrm{B}}$ values. Thus, this showed that selection of short days to heading and days to maturity is effective for the objective of improvement towards selection of early maturing genotypes Similarly selection of culm length, plant height and grain yield used for selection of high yielding genotypes. Highest heritability indicates the lesser influence of environment as compared to the genetic factors in controlling the traits and it suggested the progenies had a higher chance to perform the same as the parent. Earlier workers also reported relatively higher $\mathrm{h}^{2}$ for days to heading (86\%) and culm length (72\%) (Habtamu, 2012), days to maturity (80\%), days to heading (60\%), grain yield (61\%) and harvest index (53\%) (Abel et al., 2012). Similarly, Solomon (2010) reported that day to heading and plant height had higher $\mathrm{h}_{\mathrm{B}}^{2}$.Inconsistent with this finding; Abel et al. (2012) noted lower heritability for plant height $(17 \%)$ and panicle length (10\%) recorded. Traits such as harvesting index (41.1\%), biomass (46.9\%), number of primary panicle branches $(44.3 \%)$ and panicle length (44.2\%) exhibited moderate broad sense heritability values (Table 5). Solomon (2010) reported the above ground biomass was categorized under moderate heritability.

The estimated genetic advance (GA) (as percentage of mean) varied from $8.7 \%$ for harvest index to $21.4 \%$ for grain yield. Higher GAM (> 20 per cent) was recorded for grain yield $(21.4 \%)$ while the characters that had recorded moderate (10 to $20 \%$ ) level of GAM were biomass (10.6\%), days to grain fill period $(12.7 \%)$, day to maturity $(10.2 \%)$, day to heading $(16.2 \%)$, number of primary panicle branches (14.1\%), plant height (11.9\%), panicle length (11.0\%) and Culm length (14.9\%). Harvest index had lowest GAM (8.66\%). This finding is in agreement with Solomon (2010) where grain yield showed higher GAM (31.3\%) and panicle length had moderate GAM (15.4\%). However, harvest index is inconsistent with this finding (19.7\%).

Heritability estimates along with genetic advance are normally more helpful in predicting the gain under selection than heritability estimates alone. However, it is not necessary that a character showing high heritability will also exhibit high genetic advance (Johnson et al.1955). High heritability with high genetic advance (as percentage of the mean) was observed for grain yield in this study could be which is similar with the result of Abel et al. (2012). Such conditions are most likely caused by additive gene action, thereby, reflecting the efficiency of selection for the improvement of these traits. However; high heritability coupled with moderate genetic advance as percent of mean was observed for day to heading, Culm length, grain filling period, day to maturity and plant height. These traits are most likely controlled by both additive (genes transmitted from parents to offspring) and non-additive (interaction between genes of the same or different loci) gene actions. Harvesting index had shown moderate heritability and very low GAM which could be difficult for improvement in tef.

\subsection{Correlation Coefficient}

Correlation coefficient analysis helps to determine the nature and degree of relationship between any two measurable characters. It resolves the complex relations between the events into simple form of association. But measure of correlation does not consider dependence of one variable over the other (Falconer and Mackay, 1996). To know the nature and magnitude of relationship existing between yield and its component characters as well as the association among the components character themselves, the phenotypic and genotypic correlations among the ten characters are competed presented in tables 6 .

Grain yield showed positive and highly significant phenotypic association with Culm length $(0.84 * *)$, plant height $(0.82 * *)$, days to heading $(0.79 * *)$, biomass yield $\left(0.88^{* *}\right)$, and harvest index $(0.84 * *)$. Therefore, any improvement of these characters would result a substantial increment on grain yield. Similar finding has been reported by Solomon et al. (2009) and Ayalneh T.et al. (2012) that day to heading and plant height were significantly correlated and biomass yield and harvest index is highly and positively correlated with seed yield but; inconsistent with this finding, days to maturity indicated that highly and negatively correlated with grain yield. According to Habtamu et al. (2011), biomass yield but harvest index had positive and highly significant association with seed yield and also positively and significantly correlated with day to heading. The present study is inconsistent with the report by Habtamu et al. (2011) in which days to maturity and grain filling period had highly significant and positive phenotypic correlation with seed yield.

On the other hand, previous research reports showed that association between traits varied with location and years (AbebeTullu, 1985). Kebebew et al. (2002) reported that yield and yield 
component associations showed differences in different locations, which is signified by the variation of association observed between grain yield and component traits. Generally, grain yield was positively correlated with most traits except days to maturity, grain filling period and number of primary panicle branches.

Grain yield had positive and highly significant genotypic correlation with plant height $(0.71 * *)$, Culm length $\left(0.62^{* *}\right)$, days to heading $(0.79 * *)$, biomass yield $\left(0.78^{* *}\right)$, and harvest index $\left(0.73^{* *}\right)$ and also positively and significantly correlated with panicle length $\left(0.51^{*}\right)$. This finding is in agreement with the result reported by Solomon et al. (2009) in which plant height, days to heading, biomass yield and harvest index was positive and significant correlated with seed yield. However, the present study is inconsistent with what reported by Abel et al. (2013) in which plant height had highly significant and negative genotypic correlation with seed yield.

Table 6.Genotypic correlation coefficients $\left(\mathrm{r}_{\mathrm{p}}\right)$ ) below and Phenotypic correlation coefficients $\left(\mathrm{r}_{\mathrm{g}}\right)$ above diagonal of yield and yield related traits for the 12 tef genotypes grown at Adet (2012/13)

\begin{tabular}{|c|c|c|c|c|c|c|c|c|c|c|}
\hline Traits & CL & $\mathbf{P L}$ & PH & DH & DM & GFP & PPB & GY & BMY & HI \\
\hline CL & & $0.48 * *$ & $0.93 * *$ & $0.81^{\mathrm{ns}}$ & $0.60^{*}$ & $-0.141^{\mathrm{ns}}$ & $0.23^{\mathrm{ns}}$ & $0.84 * *$ & $0.73 * *$ & $0.73 * *$ \\
\hline PL & $0.51 * *$ & & $0.77 * *$ & $0.36^{\mathrm{ns}}$ & $0.23^{\mathrm{ns}}$ & $-0.148^{\mathrm{ns}}$ & $0.28^{\mathrm{ns}}$ & $0.51^{\mathrm{ns}}$ & $0.42 * *$ & $0.36^{\mathrm{ns}}$ \\
\hline PH & $0.98 * *$ & $0.77 * *$ & & $0.74 * *$ & $0.57^{\mathrm{ns}}$ & $-0.146^{\mathrm{ns}}$ & $0.24^{\mathrm{ns}}$ & $0.82 * *$ & $0.69 * *$ & $0.69 *$ \\
\hline DH & $0.84 * *$ & $0.35^{\mathrm{ns}}$ & $0.73 * *$ & & $0.75 * *$ & $-0.24^{\mathrm{ns}}$ & $0.14^{\mathrm{ns}}$ & $0.79 * *$ & $0.73 * *$ & $0.65 *$ \\
\hline DM & $0.63 *$ & $0.23^{\mathrm{ns}}$ & $0.56^{*}$ & $0.74 * *$ & & $0.46^{\mathrm{ns}}$ & $0.53^{\mathrm{ns}}$ & $0.51^{\mathrm{ns}}$ & $0.69 *$ & $0.20^{\mathrm{ns}}$ \\
\hline GFP & $-0.147^{\mathrm{ns}}$ & $\underset{\mathrm{ns}}{-0.15}$ & $-0.15^{n s}$ & $\underset{\mathrm{ns}}{-0.24}$ & $0.46^{\mathrm{ns}}$ & & $0.59 *$ & -0.29 & $0.04^{\mathrm{ns}}$ & $\underset{\mathrm{ns}}{-0.51}$ \\
\hline PPB & $0.28^{\mathrm{ns}}$ & $0.28^{\mathrm{ns}}$ & $0.28^{\mathrm{ns}}$ & $0.14^{\mathrm{ns}}$ & $0.53^{\mathrm{ns}}$ & $0.59 *$ & & $0.28^{\mathrm{ns}}$ & $0.49^{\mathrm{ns}}$ & $\underset{\mathrm{ns}}{0.012}$ \\
\hline GY & $0.62 * *$ & $0.50 *$ & $0.71 * *$ & $0.79 * *$ & $0.51^{\mathrm{ns}}$ & $-0.29^{\mathrm{ns}}$ & $0.28^{\mathrm{ns}}$ & & $0.88 * *$ & $0.84 * *$ \\
\hline BMY & $0.72 * *$ & $0.42^{\mathrm{ns}}$ & $0.69 *$ & $0.72 * *$ & $0.69 *$ & $0.04^{\mathrm{ns}}$ & $0.49^{\mathrm{ns}}$ & $0.78 * *$ & & $0.50^{\mathrm{ns}}$ \\
\hline HI & $0.77 * *$ & $0.39^{\mathrm{ns}}$ & $0.69 *$ & $0.67 *$ & $0.20^{\mathrm{ns}}$ & $-0.54^{\mathrm{ns}}$ & $\underset{\mathrm{ns}}{0.012}$ & $0.73 * *$ & $\underset{\mathrm{ns}}{0.001}$ & \\
\hline
\end{tabular}

*and ${ }^{* *}$ indicates significant at $5 \%$ and $1 \%$ probability levels, respectively. $C L=C u l m$ length, $P L=$ panicle length, $P H=$ plant height, $D H=$ days to heading, DM =days to maturity, GFP=grain filling period, $P P B=$ primary panicle brunch, $G Y=$ grain yield, BMY =biomass yield, $H I=$ harvest index.

Correlations among other characters like Panicle length exhibited a positive and significant phenotypic correlation with plant height and biomass yield. This finding is in agreement with Solomon et al. (2010); Habtamu et al. (2011); Abel et al. (2013).

Biomass yield had positive and highly significant phenotypic correlation with culm length $(0.73 * *)$, panicle length $(0.42 * *)$, plant height $(0.42 * *)$ and days to heading $(0.73 * *)$ and also significant correlation with day to maturity $(0.69 *)$.The positive and significant association of biomass yield with days to maturity, culm length, plant height and days to heading and among with each other, indicating that these traits can be improved simultaneously through selection.

Culm length, exhibited a positive and highly significant correlation with, panicle length $\left(0.48^{* *}\right)$, plant height $\left(0.93^{* *}\right)$ and harvest index $(0.73 * *)$ and also a positive and significant correlation with day to maturity $(0.60 *)$. Plant height had positive and highly significantly correlated with days to heading $(0.74 * *)$. Days to heading had also showed a significant positive correlation with days to maturity $\left(0.75^{* *}\right)$.

Day to heading exhibited a positive and highly significant genotypic correlation with culm length $\left(0.84^{* *}\right)$, plant height $\left(0.73^{* *}\right)$, day to maturity $(0.74 * *)$ and biomass yield $\left(0.72^{* *}\right)$ and also significant correlation with harvest index. This finding is in agreement with the finding which was reported by Abel et al. (2013) that is plant height, day to maturity and biomass yield were significantly correlated with day to heading.

Day to maturity exhibited a positive and significant genotypic correlation with Culm length $\left(0.63^{*}\right)$, plant height $\left(0.56^{*}\right)$ and biomass yield $\left(0.69^{*}\right)$. Plant height was positively and highly significantly correlated with Culm length $\left(0.98^{* *}\right)$ and panicle length $\left(0.77^{* *}\right)$ and also significantly correlated with biomass yield $\left(0.69^{*}\right)$ and harvest index $\left(0.69^{*}\right)$. Panicle length positively and strongly 
correlated with Culm length. Grain filling period positively and significantly correlated with primary panicle brunch.

Generally, positive and significant association of pairs of characters at phenotypic level and positive and high correlation genotypic level justified the possibility of correlated response to selection. The negative correlations prohibit the simultaneous improvement of those traits.

Therefore, any improvement of these characters would result in a substantial increment on grain yield. Thus, evaluation for variability of tef using conventional approach still could provide vital information but using contemporary molecular genetic analysis approaches such as mapping of quantitative trait loci using molecular markers is helpful to understand variability at molecular level, improve selection knowledge and arrive at more comprehensive conclusions. Repeating the experiment is advisable to better estimate environmental effects.

\section{CONCLUSION}

This study generally indicated that there was genetic variability among the genotypes. Thus, there is enormous opportunity in the improvement of tef genotypes. Therefore, the information generated from this study needs to be used by breeders who are interested in high yielding genotypes. Besides, these tef materials need to be tested in similar agro ecologies for their stability.

\section{ACKNOWLEDGMENTS}

The authors would like to thank BahirDar University and Adet Agricultural research center for contribution of seed.

\section{REFERENCES}

[1] AbebeTullu, 1985. Correlation and Variation Studies on Yield and Some Plant Character in Some Indigenes and Exotic Chickpea Varieties. M.Sc. thesis submitted to Addis Ababa University, Addis Ababa, Ethiopia. PP 89.

[2] Abel Debebe, Harijat Singh and HailuTefera. 2012. Genetic variability and heritability studies in f4 progenies of tef (Eragrostis tef). Asian J. Agric. Sci.4(3): 225-228

[3] Abel Debebe, Harijat Singh and HailuTefera, 2013.Interrelationship and path coefficient analysis of yield components in $\mathrm{F}_{4}$ progenies of tef (Eragrostis tef). Asian Journal of Agricultural sciences.5 (1):1-5.

[4] Arora P.P. 1991. Genetic variability and its relevance in chickpea improvement. International Chickpea Newsletter 25: 9-10.

[5] Ayalneh T., A. Amsalu and Z. Habtamu. 2012. Genetic Divergence, Trait Association and Path Analysis of TEF (Eragrostistef (Zucc.)Trotter) Lines. World Journal of Agricultural Sciences, 8 (6): 642-646.

[6] Burton Urton C.W. and Devane E.H. 1953. Estimating heritability in tall Festuca (Restucaarundinaceae) from donar material. Agron. J. 45:1476-1481.

[7] Falconer D.S. and Mackay T.F.C. 1996.Introduction to quantitative genetics.4th ed. Longman, London, UK.

[8] Fisher R.A. and Yates F. 1963.Statisticaltables for biological, Agriculture and Medical Research.6 Edition, Hafiner press, New York Pp 155.

[9] Gomez K.A. and. Gomeze A.A. 1998. Statistical Procedures for Agricultural Research.2 ${ }^{\text {nd }}$ Edition, John Wiley and Sons Inter -Science publication, New York, Chichester, Brisbane, Toronto, Singapore Pp 680.

[10] Habtamu Ayalew, 2012. Phenotypic variability in tef [Eragrostis tef (Zucc.)Trotter] landraces from Amhara region, Ethiopia. Intercontinental Journal of Agricultural Science. 1(1): 01-06

[11] HailuTefera and SeyfuKetema. 2001. Production and Importance of Tef in Ethiopian Agriculture. In: H.Tefera, G. Belay, and M. Sorrells (eds.). Narrowing the Rift: Tef research and development. Addis Ababa, Ethiopia Pp.3-7.

[12] HailuTefera, KebebewAssefa, FufaHundera, TiruneshKefiyalew and TeferaTesfaye. 2003. Heritability and genetic advance in recombinant inbred lines of tef (Eragrostis tef).Euphyteca 131:91-96.

[13] Johanson R.W., Robinson H.F. and Comstock R.E. 1955.Estimates of genetic and environmental variability in soybeans. Agron.J. 47: 314-318.

[14] KebebewAssefa, HailuTefera and ArnulfMerker, 2002. Variation and inter-relationships of quantitative traits in tef (Eragrostis tef (Zucc.)Trotter) germplasm from western and southern Ethiopia. Hereditas 136: $116-125$. 
[15] KebebewAssefa, Seyfuketema, HailuTefera, TiruneshKefiyalew and FufaHundera, 2000. Trait diversity, heritability and genetic advance in selected germplasm lines of tef [(Eragrostis tef (Zucc.) Trotter].Hereditas 133: 29-37.

[16] Khorgade P.W., Narkhede M. N. and Raut S.K. 1985. Genetic variability studies in chickpea. International Chickpea Newsletter, no.12, pp. 12-13.

[17] Misra R.C. 1991. Stability of heritability, genetic advance and character association estimates in chickpea. International Chickpea Newsletter 25:10-11.

[18] Pandey R.L. and Tawari A.S. 1983.Heritability and genetic gain in chickpea. International Chickpea Newsletter 9: 5-6.

[19] Robinson H. F., Comstock R. E. and Harvey P. H. 1949.Estimates of heritability and degree of dominance in corn. Agron. J. 41: 353-359.

[20] SAS Institute (2004). SAS/STAT user's guide.SAS Institute Inc., Cary, North Carolina, U.S.A.

[21] Seyfu Ketema. 1997. Tef.[Eragrostis tef (Zucc.)Trotter.]Promoting the conservation and use of underutilized and neglected crops. Institute of Plant Genetics and Crop Plant Research, Gatersleben/ International Plant Genetic Resources Institute, Rome, Italy. Pp 52

[22] Shivasubramanian S. and Menon M. 1973.Heterosis and inbreeding depression in rice. Madras Agric.J. 60 : 1139.

[23] Snecedor G.W., 1946. Statistical methods, The IOWA State's College Press, IOWA.

[24] Solomon Chanyalew, HailuTefera and Harjit-Singh, 2009. Genetic variability, heritability and trait relationships in recombinant inbred lines of tef [Eragrostis Tef (Zucc.) Trotter]. Research Journal of Agriculture and Biological Sciences, 5(4): 474-479,

[25] Solomon Chanyalew, 2010. Genetic analyses of agronomic traits of tef (Eragrostis tef) genotypes. Research Journal of Agriculture and Biological Sciences, 6(6): 912-916.

[26] TadesseEbba. 1975. Tef (Eragrostis tef) cultivars morphology and classification, Part II. DebreZeit Agricultural Research Station. Bulletin Number 66, Addis Ababa University, Dire Dawa, Ethiopia.

[27] Vavilov N.I. 1951. The Origin, Variation, Immunity and Breeding of Cultivated Plants. Roland Press, New York, (Translated from the Russian by K. Starrchester).

[28] WondewosenShiferaw, AlemayehuBalcha and Hussen Mohammed, 2012.Genetic Variation for Grain Yield and Yield Related Traits in Tef [Eragrostis tef (Zucc.)Trotter] under Moisture Stress and Non-Stress Environments. American Journal of Plant Sciences, 3:1041-1046

Citation: Abebe Bogale, (2019). "Genetic Variability, Heritability and Genetic Advance of Some Varieties of Tef (Eragrostis Tef (Zucc.) Trotter) in North West Ethiopia” International Journal of Research Studies in Agricultural Sciences (IJRSAS), 5(1), pp.27-37, http://dx.doi.org/10.20431/2454-6224.0501005

Copyright: (C) 2019 Authors. This is an open-access article distributed under the terms of the Creative Commons Attribution License, which permits unrestricted use, distribution, and reproduction in any medium, provided the original author and source are credited. 